\title{
Traditional market, social relations, and diversity of edible plants traded in Beringharjo Market, Yogyakarta, Indonesia
}

\author{
BUDIAWATI SUPANGKAT ISKANDAR ${ }^{1}$, JOHAN ISKANDAR ${ }^{2,3,4}$, DEDE MULYANTO ${ }^{1}$, \\ RAHMAN LATIF ALFIAN ${ }^{1}$, SUROSO ${ }^{3}$ \\ ${ }^{1}$ Department of Anthropology, Faculty of Social and Political Science, Universitas Padjadjaran. Jl. Raya Bandung-Sumedang Km 21, Jatiangor, \\ Sumedang 45363, West Java, Indonesia. Tel.: +62-22-7796416, Fax.: +62-22-7796974, ` email: budiawati.supangkat@unpad.ac.id \\ ${ }^{2}$ Program in Environmental Science, School of Graduate (PSMIL \& DIL), Universitas Padjadjaran. Jl. Sekeloa Selatan I, Bandung 40134, West Java, \\ Indonesia \\ ${ }^{3}$ Department of Biology, Faculty of Mathematics and Natural Sciences, Universitas Padjajaran. Jl. Raya Bandung-Sumedang Km 21, Jatinangor, \\ Sumedang 45363, West Java, Indonesia \\ ${ }^{4}$ Center for Environment and Sustainabilty Science, Universitas Padjadjaran. Jl. Sekeloa Selatan 1, Bandung 40134, West Java, Indonesia
}

Manuscript received: 23 March 2021. Revision accepted: 27 March 2021.

\begin{abstract}
Iskandar BS, Iskandar J, Mulyanto D, Alfian RL, Suroso. 2021. Traditional market, social relations, and diversity of edible plants traded in Beringharjo Market, Yogyakarta, Indonesia. Biodiversitas 22: 2045-2057. Although the modern markets have rapidly developed in many cities of Indonesia in the last decades, the urban traditional markets still exist in Indonesia, including Beringharjo Market, Yogyakarta. This study illustrated the story and social relation activities, biodiversity of edible plants traded, and market chain system of edible plant supplies from rural areas to Beringharjo Market. The study was conducted between February and March 2019. The method used in this study was qualitative data with an ethnobotanical approach. Some field techniques, including plant surveys and deep interviews with competent informants, were employed to collect the primary data. The result of this study showed that historically the economic activities of Beringharjo Market had been existing very a long time at least documented in 1758, while the market building was constructed by the Sultanate of Yogyakarta Palace, Sri Sultan Hamengku Buwono VIII in 1925. Like other traditional markets in Indonesia, the Beringharjo Market has played an important role in developing local economic activities, as the main place for the transaction of various edible plants and meeting for many ethnics, making the important as center of biocultural diversity at the local level. An ethnobotanical survey revealed that 93 edible plant species belonging to 37 families with a total of 159 landraces were commonly traded. The Beringharjo Market has traditionally traded a high diversity of edible plants that are supplied from local farmers productions of Yogyakarta and Central Java. Therefore, this traditional market has an important role in enhancing local economic development and contributing to promoting and conserving local plant diversity in this region.
\end{abstract}

Keywords: Beringharjo, biodiversity, edible plants, social relation, traditional market, Yogyakarta

\section{INTRODUCTION}

Traditional markets in many countries across cultures have been established long before the modern markets are developed. In the last 30 years, the supermarkets have turned in developing countries into three stages. The first stage started in the early 1990s in South America, East Asia (except China), and South Africa. The second stage began in the mid-to-late 1990s in Mexico, Central America, and Southeast Asia. The third stage refers to the rapid development of supermarkets in China, India, and Vietnam at the beginning of the late 1990s and early 2000s (Si et al. 2016).

Nowadays, although the modern markets have predominantly occurred in many countries, the traditional markets also still exist in many continents, including Europe, America, Africa, Latin America, Oceania, and Southeast Asia (Bautista-Cruz et al. 2011; Monteiro et al. 2010; Smith 2011; Supangkat-Iskandar 2012; Tinitania et al. 2016; Bussmann et al. 2018; Nguyen et al. 2019; Franco et al. 2020; Lukzaj et al. 2021).

The traditional market is different from the modern market, it has strong socio-cultural value. For instance, activities of selling and buying are directly undertaken without intermediaries. The trading commodities are strongly influenced by personal bargaining the mechanism between traders and consumers. As a result, social interaction may determine the commodities prices. Also, the traditional markets have diversities of commodities traded, traders, consumers, ethics, languages, genders, and educations (Supangkat-Iskandar 2012; Iskandar et al. 2018; Alfian et al. 2020; Franco et al. 2020).

The local commodities have been commonly traded in the traditional markets than imported commodities. Various local agricultural products, such as staple foods, fruits, and vegetables, are predominantly traded in the traditional markets (Iskandar et al. 2018). The local commodities are normally traded with lower price than that of imported commodities traded in supermarkets. Consumers usually come to the traditional markets to buy edible plant commodities that are fresh and cheap and get mutual communication and information of various plant and animal resources that are traded (Franco et al. 2020). As a result, the traditional markets have an important role as hallmarks of particular culture or society by reproducing, on small scale, the cultural and biological diversity of the 
region (Albuquerque et al. 2014). Besides, since the traditional markets have been the place of information and socialization of local knowledge or traditional ecological knowledge (TEK) of plants and animals, some studies of ethnobotany and ethnozoology are predominantly undertaken in the traditional markets of many countries across culture (Robert et al. 1983; Alves et al. 2010; Ferreira et al. 2013; Silalahi et al. 2015; Iskandar et al. 2018; Nguyen et al. 2019; Iskandar et al. 2020b; Alfian et al. 2020).

In terms of biodiversity, various plants, which have many uses including staple food and traditional medicines to maintain human health, are commonly traded in traditional markets in many countries, including Indonesia, Brunei Darussalam, Vietnam, Columbia, Brazil (Monteiro et al. 2010; Silalahi et al. 2015; Yamamoto et al. 2015; Bussmann et al. 2018; Nguyen et al. 2019; Franco et al. 2020; Iskandar 2020b; Lukzaj et al. 2021).

Diversity of both plants and animals, commonly traded in the traditional markets, are produced in local and very closely related to local culture. For example, since many local fruits have been produced from forests and traditional agroforestry areas in West Kalimantan, so that the local fruits are predominantly traded in the traditional markets within West Kalimantan (Arman 1996; Siregar 2006). In the traditional markets of West Sumba District, distinctive plant commodities, i.e. areca nuts, are predominantly traded. This is because areca nut, betel leaves, lime, and gambier are predominantly used for chewing by the local people. In addition to chewing, the areca nut is traditionally used for rituals by the people of Loli Sub-district, West Sumba, East Nusa Tenggara (Dwinanto et al. 2019).

In Ujungberung traditional market, located in Bandung West Java, vegetable commodities are mostly traded since the Sundanese tremendously like fresh vegetables for the main menu of their daily meals. Besides, some mountainous areas in West Java, including Lembang, Ciwidey, and Majalaya that have volcanoes, fertile soil, and cool air, are appropriate for cultivating vegetables (Iskandar et al. 2018). With regards to edible plant commodities, the traditional market in Central Java, including Pati is different from West Java, it has various traditional medicinal plants traded (Irwanta et al. 2012), because the Javanese, including Pati, prefer to consume 'jamu' which is made from various medicinal plants. Another example in Bali, the flowers have commonly used for traditional rituals and are predominantly demanded, it resulted in the flowers are largely traded in traditional markets in Bali, including Tabanan traditional markets (Sujarwo et al. 2018).

Since Indonesia has a high diversity of ethnics as well as local ecosystems, various edible plants are commonly sold in the traditional market of Indonesian cities. It has been known that traditional markets in many cities and many towns in many countries as places of intensive interaction among people (vendors and consumers), people and plants, and source of ethnobotanical information and folk knowledge on useful plant species (Monteiro 2010). Moreover, some studies on ethnobiology and ethnobotany have been undertaken by scholars in many market places in different countries (Alves et al. 2010; Ferreira et al. 2013; Silalahi et al. 2015; Iskandar et al. 2018; Sujarwo et al. 2018; Nguyen et al. 2019; Iskandar et al. 2020b; Alfian et al. 2020; Manzanero-Medina et al. 2020).

Although plant species traded in traditional markets located in the cities have been the subject of studies across a range of academic disciplines in many regions of Indonesia, the study on plant species in different traditional markets of Indonesia is considered essential since various plants traded in the traditional markets are generally determined by specific local culture and indigenous ecosystem.

This study illustrates the story and social relation activities, biodiversity of edible plants traded, and market chain system of edible plant supplied from rural areas to Beringharjo Market, Yogyakarta.

\section{MATERIALS AND METHODS}

\section{Study area}

The study was undertaken in Beringharjo Market, a special region of Yogyakarta, before the Covid-19 pandemic, between February and March 2019. Geographically, Yogyakarta province is located between $07^{0} 15^{\prime} 24^{\prime \prime}-07^{0} 49^{\prime} 26^{\prime \prime}$ South and $110^{\circ} 24^{\prime} 19^{\prime \prime}-110^{\circ} 28^{\prime} 53$ '” East (Figure 1). The province is bordered by the Indonesian Ocean to South, and Central Java including the district of Klaten, Wonogiri, Purworejo, and Magelang to North, Southeast, West and Northwest, respectively (Statistical Data of Yogyakarta 2012).

The Beringharjo Market is situated in the city center of Yogyakarta, precisely located in Ahmad Yani Street No 1. The market is located at the southern tip of Malioboro (Figure 2). It is adjacent to Vredeburg Port, Grand Building (Gedung Agung), Yogyakarta Cultural Park, trading book center (Taman Pintar), and Shopping Center.

The specialty of Yogyakarta is set based on its history, it was led by aristocratic and has social culture embedded with Javanese tradition. Malioboro is an iconic street of Yogyakarta and is known as one of the tourist destinations for both national and international tourists (Cahya et al. 2017). For the greening of the city along Malioboro street, various trees, including Javanese tamarind (Tamarindus indica), are dominantly planted. Tourists can walk along the sidewalk, as well as relax and sit down to enjoy the nuance of Malioboro street, also beautiful chairs are specially provided for tourists along the street. Meanwhile, various goods including t-shirts, wallets, hats, and local food are sold by street vendors in front of shops along the sidewalks.

Since the Beringharjo Market is located very close to the Malioboro street center, many people consist of local people, and tourists have commonly visited this traditional market to buy various commodities. In other words, the market has been an important role as one of the trading centers of Yogyakarta as well as one of the famous tourist destinations. 


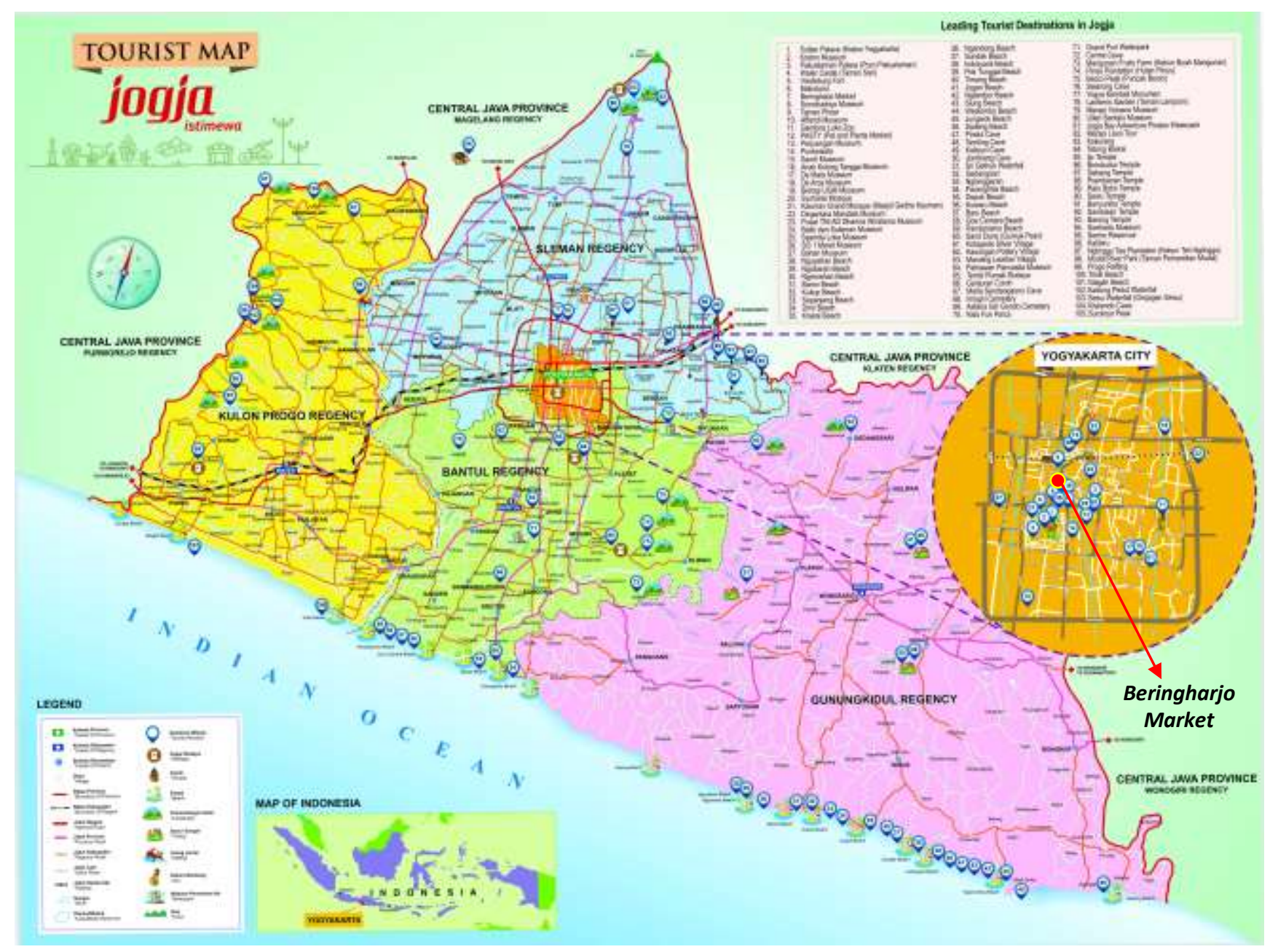

Figure 1. Study area. Source: Tourism office of Yogyakarta special Region (2019)

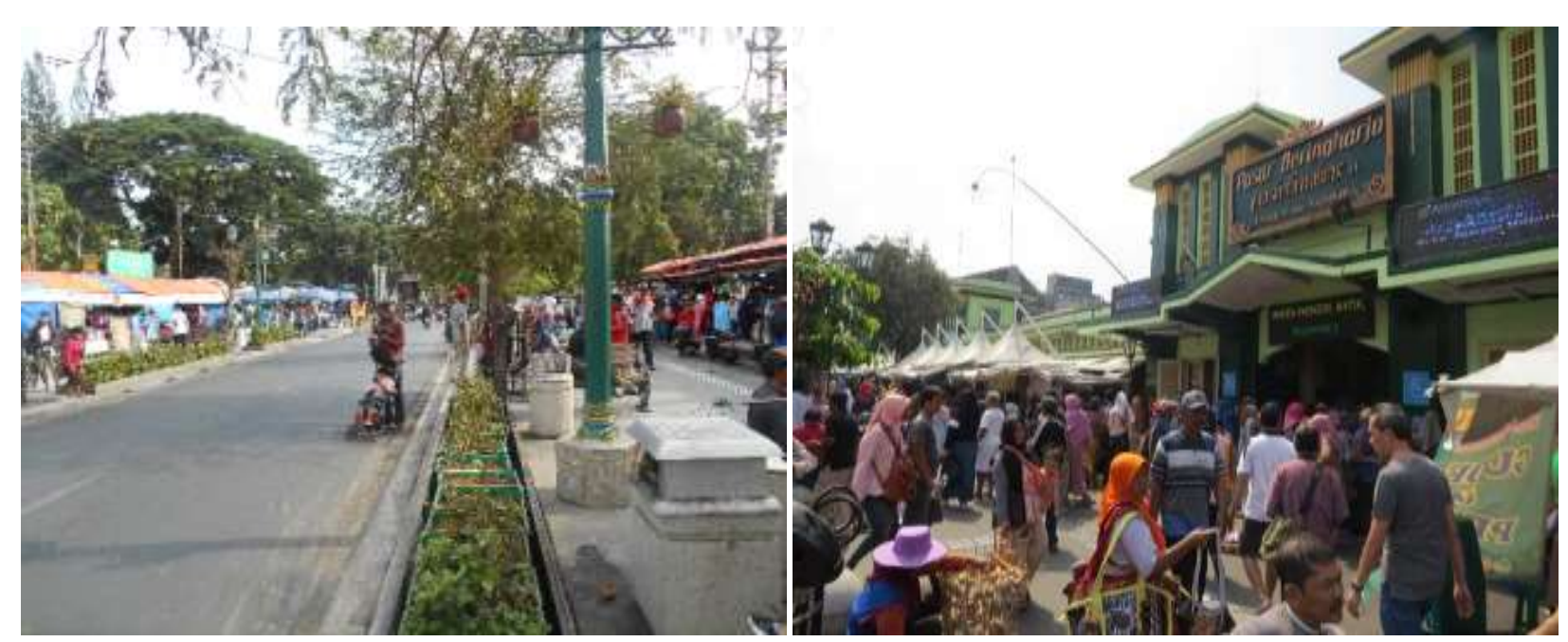

Figure 2. Left-Malioboro street is located at the front of Beringharjo Market. Right- the main entrance for entering the market

\section{Data collection}

The method used in this study was qualitative with the ethnographical approach (Spradley 1980) and ethnobotanical approach applied (Martin 1995; Cunningham 2001;
Albuquerque et al. 2014). Some techniques, including observation, deep interviews were employed with competent informants to document edible plants traded in Beringharjo Market. Observation was undertaken to 
observe the traditional market conditions, including market buildings, kiosks, and stalls where traders sell their commodities. A deep interview was employed to obtain some information about various edible plants that are sold in the market, including the local name of each edible plant species, main function, part of plant used, area of each edible plant come from, and market chain system. While, survey of edible plant traded was intended to elicit data of various edible plants traded by each trader.

We conducted observation for a total of ten days with each consecutive day visiting the Beringharjo market in the morning or during regular hours (cf. Nguyen 2005; Alburquerque et al. 2014). Each day, we visited the market in the early morning approximately between $02: 00$ to 7:00 am. Arriving early enables us to observe traders coming to the market, including preparing and putting all commodities in the stall. Observation in early morning was undertaken in the eastern side of Beringharjo Market. At that time, some traders have come and traded their commodities outside the market building and cars that supplying vegetable commodities came and started peddling the commodities in the eastern side of the market.

Approximately at 4:30 am, the snacks' traders, including tempeh, tofu, mushrooms, and others started to prepare and put their commodities at the stall on the first floor of the Market. The trading activities on the first floor ended at 07:00 am.

The observation was also continued between 07:00 am and 02:00 pm, we observed traders' activities on the second floor of the eastern side of the market. At that time, traders of vegetables and fruits started to open their kiosks and stalls. At the same time, all traders inside the market building were starting to sell their commodities. The market activities usually ended at 02:00 pm, and all traders closed the kiosks and stalls.

Deep interviews regarding each edible plant species, including local name, main uses, plant part, and area where the commodities come from were employed with competence informants. The informants were purposively selected based on gender and commodities sold. Our informants were traders of vegetables, fruits, spices, additional staple foods, medicinal plants (empon-empon), middlemen, market laborers, market security, and staff of Agency of Trade, Industry and Market of Yogyakarta Province. During the interview, informants provided extensive responses to a series of general questions, some of which have been prepared in advance as the interview guide (panduan wawancara) and naturally during the conversation (Martin 1995).

While a survey of edible plant species was undertaken by documenting and identifying edible plant species that were being traded. Some species that could not directly be identified in the market were made into the photograph and the voucher specimen (Albuquerque et al. 2014).

\section{Data analysis}

The data obtained from both observation and deep interviews were analyzed into several stages, namely crosschecking, summarizing and synthesizing, and making a narrative account (Newing et al. 2011). Cross-checking was made to examine veritable data obtained, and some false data were not used. The cross-checked data were summarized, synthesized, and made into a narrative account with descriptive analysis and evaluation.

Some edible plant species, particularly unidentified species were identified in the taxonomy laboratory of the Department of Biology, Faculty of Mathematics and Natural Science, Padjadjaran University. Some books, including Backer and Bakhuizen v.d. Brink (1968), Heyne (1987), Partoharjono and Grubben (1996), and Siemonsa and Grubben 1996 were used to identify the plant species.

\section{RESULTS AND DISCUSSION}

\section{Market story and social relation}

The Beringharjo market of Yogyakarta has been considered a unique name. It is based on environmental history. Beringharjo was taken from the origin of where the market was founded. The initial location of the market as known at present time was recognized in the past as a forest ecosystem that was predominantly grown by banyan tree or beringin, waringin in Javanese (Ficus benjamina L., Family Moraceae family). As a result, Beringharjo word comes from bering and raharjo which has a literal meaning as 'prosperous banyan forest' (hutan beringin yang sejahtera). In other words, the traditional market may hopefully bring prosperity for all people.

Economic activities in the market of Beringharjo began after Keraton Ngayogyakarta Hadiningrat was built in 1758 (Herliana 2014). In the past, before the market had been permanently built, the traders sold their commodities in simple stalls made of wood. The permeant building of Beringharjo was built by the sultanate of Yogyakarta Palace, Sri Sultan Hamengku Buwono VIII in collaboration with the Nederlansch Indisch Beton Maatschappij (the Dutch Indies Concrete Company) in 1925. At that time, it was constructed permanent stalls (Los Pasar), particularly in the Western side of the market. Beringharjo name was given by Sri Sultan Hamengkubiwono VIII when he was appointed as a sultanate of Yogyakarta palace.

The Beringharjo market was documented to have been hit by the fire in 1925. As a result, it was rebuilt with a multi-story model, whereas before the fire the building was not multi-story. After completing the rebuilt, traders started occupying the new building in 1991.

The Beringharjo market, where the traders sell their products, consists of five parts, namely: (i) kiosk in the form of a permanent building with casting, intended to trade nine basic necessity (sembako), i.e. rice, sugar, cooking oil, butter, beef, chicken, chicken egg, milk, corn, kerosene, and salt; (ii) kiosk using wood, purposed to trade vegetables, herbal medicine (jamu), and batik and clothes; (iii) kiosk in the form of wood and casted building, aimed to trade various snacks; (iv) stalls made of wood and casted building, intended to trade vegetables, and various meats; and (v) the spread of tarpaulin mat or sack, normally used for vegetable and market snacks in the morning, located outside the market building (Figure 3). 

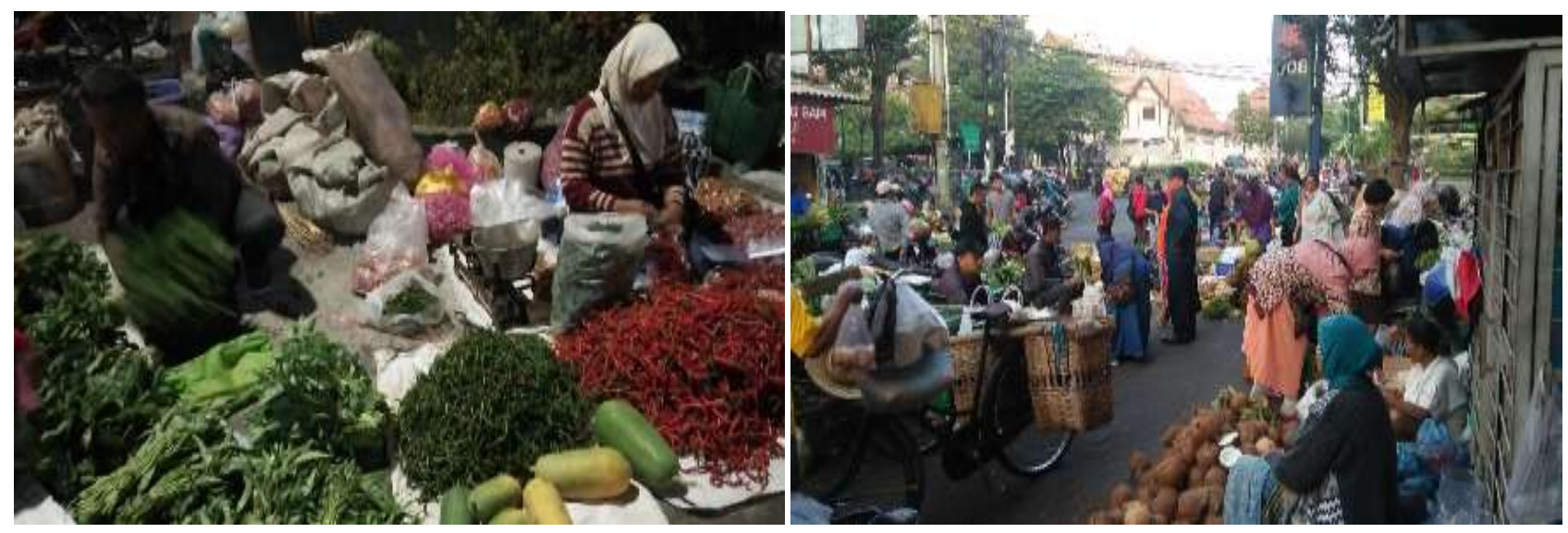

Figure 3. Left-early morning market is commonly happened outside of the market building, vegetables are predominantly sold. RightVegetable and snack sold in early morning market.

Based on bulk commodity selling, the traders can be divided into two categories, i.e. grocers and retailers. The grocers commonly sell in large quantities, while the retail generally sells in small quantities. Both grocers and retailers have specific subscription buyers. The grocers usually sell their commodities to retailers or sellers who want to resell their commodities. While the retailers normally sell their goods to individual household consumers. In general, the commodities sold by grocers are cheaper than the selling price by retails, but buying from grocers must be in large quantities, and these items will be sold again by retailers. In other words, the buyers at grocers are retailers, while buyers at retailers are individual households.

For vegetable traders, they usually sell their commodities predominantly to retailers as well as to grocers in large quantities. For selling large quantities of vegetables, the traders usually sell to special regular retailers. The quantity and kind of vegetable are ordered the day before through face-to-face between sellers and buyers, or via mobile.

The buying and selling system in Beringharjo Market has generally a strong social system and is embedded with culture. The relationship between traders and buyers is very close. For example, traders often offer their commodities to consumers and market visitors who pass by to their place of sale. The price offered by the trader to the buyer is also not a fixed price, but the buyer can bargain it and the price is subject to change. Therefore, the bargaining process between traders and buyers is very common in the traditional market system (Iskandar et al. 2018). Most of the bargaining process uses the local language, i.e. Javanese. Although there are also some cases where traders offer their merchandise in the Indonesian language, especially for the tourists who shop at the Beringharjo Market.

The social relations built between traders and buyers and between one trader and other traders in the Beringharjo market can be considered very intimate, especially among traders who are close to the side, front, and back where they trade. This kind of relationship is reflected in daily activities. Several times we have encountered cases that traders put their trust in their merchant's neighbor to be entrusted with the merchant's kiosk because they left the kiosk for a while for specific purposes. For example, when entering prayer time, traders will turn to keep a kiosk with their nearby neighbors, when a buyer comes to buy goods from a neighbor's commodity, it is very common for the traders whom they entrusted to voluntarily serve the buyer.

Traders usually also exchange commodities when a buyer is looking for a certain commodity. It turns out to be out of stock. The trader will look for similar commodity to other traders, in the local term it is called nempil, later it will then be paid at the basic cost of goods sold or replaced with similar commodities when a substitute is available later on.

In addition to the relationship among traders, the relationship between the traders and the female carry workers (embok gendong) is also going well. Many times we encountered "embok gendong" having the task of opening the kiosk first before the kiosk owner comes to the market. "Embok gendong" will also serve if there are buyers who buy and also prepare commodities before the kiosk owner comes. For this relationship, usually the "embok gendong" gets a certain amount of reward from the kiosk owner.

The relationship between traders and buyers in the Beringharjo market is built with a sense of kinship system. Many times we encountered traders giving bonuses to their subscribers (pembeli langganan). These bonuses can be in the form of reduced prices or additional items purchased. Apart from that, traders also come to the house of very regular buyers (pembeli langganan) if their customers have a feast. Some traders also give trust to their customers (regular buyers) by providing debt.

Information technology has also influenced the way of trading in the traditional market system. For instance, traders can order commodities from suppliers via mobile phones. , The traders also serve orders to customers via mobile. 


\section{Species diversity and plant variations}

Based on edible plants traded in the Beringharjo market, the study documented 159 landraces (plant variations) belonging to 93 plant species, and 37 families (Table 1). It can be seen that the rich diversity of the edible plant landraces are commonly traded in the Beringharjo market. For instance, from the total number of species, 16 species $(17.2 \%)$ recorded have landraces, some of them are Musa x paradisiaca (11 landraces), Oryza sativa (10 landraces), and Zingiber officinale (4 landraces) (Table 2) (Figure 4).

The Beringharjo market is similar to Ujungberung traditional market, located in Bandung West Java. The Ujung Berung market has also high diversity of species and races of edible plant traded. The market encountered 120 edible plant species representing 44 families and amounted to 188 variations (landraces) (Iskandar et al. 2018).

The landraces diversity, including banana and rice encountered in the traditional markets both Beringharjo and Ujungberung, can reflect on the cultural and biological diversity of a region. For example, since the farmers in West Java and Yogyakarta have cultivated the high landraces diversity of banana and rice, both commodities are higher in Ujungberung and Beringharjo. Besides, since the empon-empon has highly demanded in Yogyakarta and Central Java, the landraces of empon-empon, including Zinger officinale, are higher in the Beringharjo market.

Based on 37 edible plant families recorded, five Families have high species number, i.e. Fabaceae 16 species (17.20 \%), Poaceae 14 species $(15.0 \%)$, Solanaceae 13 (13.9\%), Brassicaceae 10 species (10.7\%), and Zingiberaceae 10 species (10.7\%) (Table 3). In addition to high species diversity, particularly the Poaceae family possesses also high diversity of landraces. At least 10 landraces, including beras 64, beras Bulog, beras C5, beras ketan hitam, beras ketan putih, beras mentik wangi, meras merah cempo, beras merah andle, beras rojo lele, and beras TR are commonly traded in Beringharjo Market (Table 1).

\section{Plant use}

We recorded 93 species belonging to 37 families with 159 landraces, which can be classified into seven main usecategories, i.e. staple food, additional staple food, fruit, vegetable, spice, spice as vegetable, and spice with medicinal values. From such use-categories, three categories have a great species number, i.e. fruit (55 species; $59.1 \%$ ), vegetable (49 species; $52.6 \%$ ), and spice (15 species; $16.1 \%$ ) are commonly traded in the Beringharjo traditional market (Figure 5). Among fruits, some species are categorized as local fruits, including kledung/kesemek (Diospyros kaki), sawo kecik (Manilkara kauki), and ciplukan (Physalis angulata) (Figure 6). Besides local fruits, mangga (Mangifera indica), jeruk (Citrus sinensis), apel Malang (Malus domestica), apel impor (Malus domestica) are mainly traded in the Beringharjo traditional market, while vegetables consists of kubis (Brassica oleracea), kacang panjang (Vigna unguiculata), wortel (Daucus carota), and tomat (Figure 7).

We can see that the Beringharjo market is similar to the Ujungberung in terms of three main use-categories, i.e. fruit, vegetable, and spice are predominantly traded in the markets. In the Ujungberung market, most dominant species belong to vegetables with 103 species $(85.8 \%)$, and other sub-dominant use-categories such as spice 58 $(48.3 \%)$, and fruit $39(32.5 \%)$. The Sundanese like very much fresh vegetables for their daily menu are many mountain areas that are considered best for cultivation of vegetable plant, so that vegetable are very abundant in the Ujungberung market (Iskandar et al. 2018).
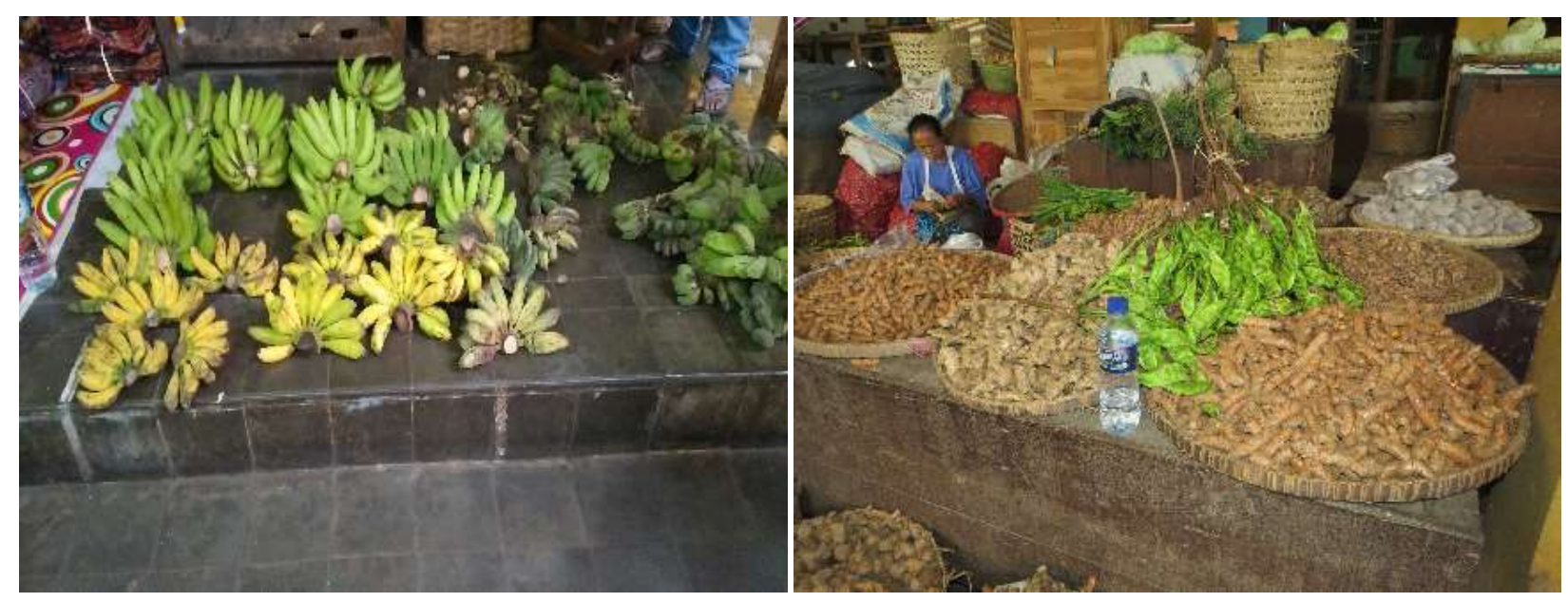

Figure 4. Left-Various banana fruits with rich variations predominantly sold. Right-Empon-empon (Zingiberaceae family) is commonly sold in the Beringharjo market. 
Table 1. Various edible plants commonly traded in Bringharjo Market, Yogyakarta, Indonesia

\begin{tabular}{|c|c|c|c|c|}
\hline $\begin{array}{l}\text { Vernacular name/Indonesian name } \\
\text { [Common name] }\end{array}$ & Scientific name & Family & Category & $\begin{array}{c}\text { Part of } \\
\text { plant used }\end{array}$ \\
\hline Alpuket [Avocado] & Persea americana Mill. & Lauraceae & Fruit & Fruit \\
\hline Anggur hijau [Grape] & Vitis vinifera $\mathrm{L}$. & Vitaceae & Fruit & Fruit \\
\hline Anggur merah [Grape] & Vitis vinifera $\mathrm{L}$. & Vitaceae & Fruit & Fruit \\
\hline Anggur ungu [Grape] & Vitis vinifera $\mathrm{L}$. & Vitaceae & Fruit & Fruit \\
\hline Apel impor [Grape) & Malus domestica Borkh. & Rosaceae & Fruit & Fruit \\
\hline Apel malang [Malang Grape] & Malus domestica Borkh. & Rosaceae & Fruit & Fruit \\
\hline Apel washington [Grape] & Malus domestica Borkh. & Rosaceae & Fruit & Fruit \\
\hline Asem jawa [Tamarind] & Tamarindus indica $\mathrm{L}$. & Fabaceae & Spices & Fruit, seed \\
\hline Bawang bombay [Onion] & Allium cepa $\mathrm{L}$. & Alliaceae & Spices & Bulb \\
\hline Bawang kating/Bawang putih [Garlic] & Allium sativum $\mathrm{L}$. & Alliaceae & Spices, vegetable & Bulb \\
\hline Bawang sicho [Garlic] & Allium sativum $\mathrm{L}$. & Alliaceae & Spices, vegetable & Bulb \\
\hline Bayem [Spinach] & Amaranthus sp. & Amaranthaceae & Vegetable & Leaf \\
\hline Bayem merah [Chinese spinach] & Amaranthus tricolor $\mathrm{L}$. & Amaranthaceae & Vegetable & Leaf \\
\hline Belimbing [Star fruit] & Averrhoa carambola $\mathrm{L}$. & Oxalidaceae & Fruit & Fruit \\
\hline Bengkoang [Yam bean] & Pachyrhizus erosus (L.) Urb. & Fabaceae & Fruit & $\begin{array}{l}\text { Tuberous } \\
\text { root }\end{array}$ \\
\hline Beras 64 [Rice] & Oryza sativa $\mathrm{L}$. & Poaceae & Staple food & Seed \\
\hline Beras bulog [Rice] & Oryza sativa $\mathrm{L}$. & Poaceae & Staple food & Seed \\
\hline Beras C5 [Rice] & Oryza sativa $\mathrm{L}$. & Poaceae & Staple food & Seed \\
\hline Beras ketan hitam [Sticky Rice] & Oryza glutinosa Lour. & Poaceae & Staple food & Seed \\
\hline Beras ketan putih [Sticky Rice] & Oryza glutinosa Lour. & Poaceae & Staple food & Seed \\
\hline Beras mentik wangi [Rice] & Oryza sativa $\mathrm{L}$ & Poaceae & Staple food & Seed \\
\hline Beras merah cempo [Rice] & Oryza sativa $\mathrm{L}$. & Poaceae & Staple food & Seed \\
\hline Beras merah andel [Rice] & Oryza sativa L & Poaceae & Staple food & Seed \\
\hline Beras rojo lele [Rice] & Oryza sativa $\mathrm{L}$. & Poaceae & Staple food & Seed \\
\hline Beras TR [Rice] & Oryza sativa $\mathrm{L}$. & Poaceae & Staple food & Seed \\
\hline Bit [Beet] & Beta vulgaris $\mathrm{L}$. & Amaranthaceae & Vegetable & Root \\
\hline Bligo [Waxgourd] & Benincasa hispida (Thunb.) Cogn. & Cucurbitaceae & Vegetable & Fruit \\
\hline Brambang brebes [Garden onion] & Allium cepa L. var. aggregatum & Alliaceae & Spices, vegetable & Bulb \\
\hline Brambang jowo [Garden onion] & Allium cepa L. var. aggregatum & Alliaceae & Spices, vegetable & Bulb \\
\hline Brambang nawungan [Garden onion] & Allium cepa L. var. aggregatum & Alliaceae & Spices, vegetable & Bulb \\
\hline Brambang solo [Garden onion] & Allium cepa $\mathrm{L}$. var. aggregatum & Alliaceae & Spices & Bulb \\
\hline Brambang temanggug [Garden onion] & Allium cepa $\mathrm{L}$. var. aggregatum & Alliaceae & Spices, vegetable & Bulb \\
\hline Brokoli [Broccoli] & Brassica oleracea var. italica Plenck & Brassicaceae & Vegetable & Leaf \\
\hline Buah naga [Night blooming cactus] & Hylocereus undatus (Haw.) Britton \& Rose & Cactaceae & Fruit & Fruit \\
\hline Buah pir [Pear] & Pyrus communis $\mathrm{L}$. & Rosaceae & Fruit & Fruit \\
\hline Cabe kriting [Cayenne pepper] & Capsicum annuиm $\mathrm{L}$. & Solanaceae & Spices, vegetable & Fruit \\
\hline Caisim (sawi ijo) [Cassin] & $\begin{array}{l}\text { Brassica rapa var. parachinensis (Bailey) } \\
\text { Hanelt }\end{array}$ & Brassicaceae & Vegetable & Fruit \\
\hline $\begin{array}{l}\text { Ciplukan/Ceplukan [Cut leaf ground } \\
\text { cherry] }\end{array}$ & Physalis angulata $\mathrm{L}$. & Solanaceae & Fruit & Fruit \\
\hline Daun bawang [Welsh onion] & Allium fistulosum L. & Alliaceae & Vegetable & Leaf \\
\hline Gambas/Oyong [Sponge gourd] & Luffa acutangula (L.) Roxb. & Cucurbitaceae & Vegetable & Fruit \\
\hline Gedang ambon [Banana] & Musa $\times$ paradisiaca $\mathrm{L}$ & Musaceae & Fruit & Fruit \\
\hline Gedang kapas [Banana] & Musa $\times$ paradisiaca $\mathrm{L}$. & Musaceae & Fruit & Fruit \\
\hline Gedang kapendish [Banana] & Musa $\times$ paradisiaca $\mathrm{L}$. & Musaceae & Fruit & Fruit \\
\hline Gedang kepok abang [Banana] & Musa $\times$ paradisiaca $\mathrm{L}$. & Musaceae & Fruit & Fruit \\
\hline Gedang kepok kuning [Banana] & Musa $\times$ paradisiaca $\mathrm{L}$. & Musaceae & Fruit & Fruit \\
\hline Gedang kepok putih [Banana] & Musa $\times$ paradisiaca $\mathrm{L}$. & Musaceae & Fruit & Fruit \\
\hline Gedang mas [Banana] & Musa $\times$ paradisiaca $\mathrm{L}$. & Musaceae & Fruit & Fruit \\
\hline Gedang muli [Banana] & Musa $\times$ paradisiaca $\mathrm{L}$. & Musaceae & Fruit & Fruit \\
\hline Gedang rojo/Gedang raja [Banana] & Musa $\times$ paradisiaca $\mathrm{L}$. & Musaceae & Fruit & Fruit \\
\hline Gedang rojo nongko [Banana] & Musa $\times$ paradisiaca $\mathrm{L}$. & Musaceae & Fruit & Fruit \\
\hline Gedang susu [Banana] & Musa $\times$ paradisiaca $\mathrm{L}$. & Musaceae & Fruit & Fruit \\
\hline Gembili [Lesser yam] & Dioscorea esculenta (Lour.) Burkill & Dioscoreaceae & $\begin{array}{l}\text { Additional staple } \\
\text { food }\end{array}$ & Tuber \\
\hline Genjer [Sawah Letuce] & Limnocharis flava (L.) Buchenau & Alismataceae & Vegetable & Leaf \\
\hline Jagung merah [Corn] & Zea mays $\mathrm{L}$. & Poaceae & $\begin{array}{l}\text { Additional staple } \\
\text { food }\end{array}$ & Fruit \\
\hline Jagung putih [Corn] & Zea mays L. & Poaceae & Additional food & Fruit \\
\hline Jagung sayur [Corn] & Zea mays L. & Poaceae & Vegetable & Fruit \\
\hline Jahe emprit [Garden ginger] & Zingiber officinale Roscoe & Zingiberaceae & $\begin{array}{l}\text { Species, traditional } \\
\text { medicine }\end{array}$ & Rhizome \\
\hline
\end{tabular}


Jahe gajah [Garden ginger]
Jahe merah [Garden ginger]

Jahe sunti [Garden ginger]

Jambu biji [Guava]

Jambu dalaru/Jambu air [Water apple] Jengkol [Jeering]

Jeruk Baby [Sweet orange]

Jeruk bali [Pomelo]

Jeruk kuning [Pomelo]

Jeruk lemon [Pumelo]

Jeruk nipis [Lime]

Jeruk peres [Pomelo]

Jeruk purut [Kaffir lime]

Jeruk sunkist [Pomelo]

Jipang [Chayote]

Kacang ijo demak [Mung bean]

Kacang ijo impor [Mung bean]

Kacang merah [Kidney bean]

Kacang merah/Kacang putih [Kidney

bean]

Kacang panjang [Cow pea]

Kacang tanah [Peanut]

Kacang tolo impor [Cow pea]

Kacang tolo jawa [Blackeyed pea]

Kambil [Coconut]

Kangkung [Swamp Morning Glory]

Kapri [Garden pea]

Kapulaga [Cardamom]

Kates [Pawpaw]

Kayu manis [Java Cinnamon]

Kedele [Soybean]

Kedondong [Golden apple]

Kemangi [Holy basil]

Kembang kol [Cauliflower]

Kembang turi (Vegetable humming

bird]

Kencur [Aromatic ginger]

Kenikir [Wild cosmos]

Kentang [Potato]

Klendung/kesemek [Persimmon]

Kluwek [Football fruit]

Kolang-kaling [Sugar palm]

Kubis [Cabbage]

Kunir [Common turmeric]

Kunir putih [Zedoary]

Kurma [Date palm]

Kweni [Kwini]

Laos [Greater galangal]

Lengkeng [Longan]

Lobak [Radish]

Lombok kriting ijo [Cayenne pepper]

Lompong [Coco yam]

Manggis [Mangosteen]

Melon [Cantaloupe]

Miri/Kemiri [Candlenut]

Mlinjo [Melinjo]
Zingiber officinale Roscoe

Zingiber officinale Roscoe

Zingiber officinale Roscoe

Psidium guajava $\mathrm{L}$.

Syzygium aqueum (Burm.f.) Alston

Archidendron pauciflorum (Benth.)

I.C.Nielsen

Citrus sinensis (L) Osbeck

Citrus maxima (Burm.) Merr.

Citrus sinensis (L.) Osbeck

Citrus limon (L.) Osbeck

Citrus aurantiifolia (Christm.) Swingle

Citrus sinensis (L.) Osbeck

Citrus hystrix DC.

Citrus sinensis (L) Osbeck

Sechium edule (Jacq.) Sw.

Vigna radiata (L.) R.Wilczek

Vigna radiata (L.) R.Wilczek

Phaseolus vulgaris $\mathrm{L}$.

Phaseolus vulgaris L.

Vigna unguiculata (L.) Walp.

Arachis hypogaea $\mathrm{L}$.

Vigna unguiculata (L.) Walp.

Vigna unguiculata (L.) Walp.

Cocos nucifera $\mathrm{L}$.

Ipomoea aquatica Forssk.

Pisum sativum $\mathrm{L}$.

Elettaria cardamomum (L.) Maton

Carica papaya $\mathrm{L}$.

(L.) Maton Zingiberaceae

Cinnamomum burmanni (Nees \& T.Nees) Blume

Glycine max (L.) Merr.

Spondias dulcis Parkinson

Ocimum tenuiflorum L.

Brassica oleracea var. botrytis $\mathrm{L}$.

Sesbania grandiflora (L.) Pers.

Kaempferia galanga L.

Cosmos caudatus Kunth

Solanum tuberosum $\mathrm{L}$.

Diospyros kaki L.f.

Pangium edule Reinw.

Arenga pinnata (Wurmb) Merr.

Brassica oleracea var. capitata $\mathrm{L}$.

Curcuma longa $\mathrm{L}$.

Curcuma zedoaria (Christm.) Roscoe

Phoenix dactylifera L.

Mangifera odorata Griff.

Alpinia galanga (L.) Willd.

Dimocarpus longan Lour.

Raphanus raphanistrum subsp. sativus (L. Brassicaceae

) Domin

Capsicum annuum $\mathrm{L}$.

Colocasia esculenta (L.) Schott

Garcinia $\times$ mangostana $\mathrm{L}$.

Cucumis melo $\mathrm{L}$.

Aleurites moluccanus (L.) Willd.

Gnetum gnemon L.

Zingiberaceae
Zingiberaceae
Zingiberaceae

Myrtaceae

Myrtaceae

Fabaceae

Rutaceae

Rutaceae

Rutaceae

Rutaceae

Rutaceae

Rutaceae

Rutaceae

Rutaceae

Cucurbitae

Fabaceae

Fabaceae

Fabaceae

Fabaceae

Fabaceae

Fabaceae

Fabaceae

Fabaceae

Arecaceae

Convolvulaceae

Fabaceae

Caricaceae

Lamiaceae

Fabaceae

Sapindaceae

Lamiaceae

Brassicaceae

Fabaceae

Zingiberaceae

Asteraceae

Solanaceae

Ebenaceae

Achariaceae

Arecaceae

Brassicaceae

Zingiberaceae

Zingiberaceae

Arecaceae

Anacardiaceae

Zingiberaceae

Sapindaceae

Solanaceae

Araceae

Clusiaceae

Cucurbitaceae

Euphorbiaceae Gnetaceae

Spice
Spice
Spice, traditional
medicine
Fruit

Fruit

Vegetable

Fruit

Fruit

Fruit

Fruit

Fruit

Fruit

Fruit

Fruit

Vegetable

Vegetable

Vegetable

Vegetable

Vegetable

Vegetable

Spices, vegetable

Vegetable

Vegetable

Fruit

Vegetable

Vegetable

Spice

Fruit

Spice

Vegetable

Fruit

Vegetable

Vegetable

Vegetable

Rhizome

Rhizome

Rhizome

Fruit

Fruit

Fruit

Fruit

Fruit

Fruit

Fruit

Fruit

Fruit

Fruit, leaf

Fruit

Fruit

Fruit

Fruit

Fruit

Fruit

Fruit

Seed

Fruit

Fruit

Fruit

Leaf, stem

Fruit, seed

Seed

Fruit

Bark

Fruit

Fruit

Leaf

Leaf

Flower

Spice, traditional medicine

Vegetable

Additional food

Rhizome

Leaf

Tuber

cauligenous

Fruit

Vegetable

Fruit

Fruit

Fruit

Fruit

Leaf

Rhizome

Spices,

Traditional

medicine

Spices, traditional medicine

Fruit

Fruit

Spiced, traditional medicine

Fruit

Vegetable

Rhizome

Fruit

Fruit

Rhizome

Fruit

Tuberous

root

Spices

Vegetable

Fruit

Leaf midrib,

leaf

Fruit

Fruit

Fruit

Fruit

Fruit

Vegetable 


\begin{tabular}{|c|c|c|c|c|}
\hline Mrico [Black pepper] & Piper nigrum L. & Piperaceae & Spices & Fruit \\
\hline Nanas [Pineapple] & Ananas comosus (L.) Merr. & Bromeliaceae & Fruit & Fruit \\
\hline Nangka [Jackfruit] & Artocarpus heterophyllus Lam. & Moraceae & Fruit & Fruit \\
\hline Pandan [Screwpine] & Pandanus amaryllifolius Roxb. & Pandanaceae & Spices & Leaf \\
\hline Paprika [Cayenne pepper] & Capsicum аппиит $\mathrm{L}$. & Solanaceae & Vegetable & Fruit \\
\hline Pare [Bitter gourd] & Momordica charantia $\mathrm{L}$. & Cucurbitaceae & Vegetable & Fruit \\
\hline Pekcoy/Sawi sendok [Rape mustard] & Brassica rapa var. chinensis (L.) Kitam. & Brassicaceae & Vegetable & Leaf \\
\hline Pelem golek [Mango] & Mangifera indica $\mathrm{L}$. & Anacardiaceae & Fruit & Fruit \\
\hline Pelem Indramayu [Mango] & Mangifera indica $\mathrm{L}$. & Anacardiaceae & Fruit & Fruit \\
\hline Pete [Stink bean] & Parkia speciosa Hassk. & Fabaceae & Vegetable & Fruit \\
\hline Puhung/Singkong [Cassava] & Manihot esculenta Crantz & Euphorbiaceae & Staple food & Tuber \\
\hline Rawit ijo [Cayenne pepper] & Capsicum аппиит L. & Solanaceae & Spices & Fruit \\
\hline Salak madu [Snake palm] & Salacca zalacca (Gaertn.) Voss & Arecaceae & Fruit & Fruit \\
\hline Salak pondoh [Snake palm] & Salacca zalacca (Gaertn.) Voss & Arecaceae & Fruit & Fruit \\
\hline Salam [Indian Bayleaf] & Syzygium polyanthum (Wight) Walp. & Myrtaceae & Spices & Leaf \\
\hline Sawi [Field mustard] & Brassica rapa $\mathrm{L}$. & Brassicaceae & Vegetable & Leaf \\
\hline Sawi (baru) [Field mustard] & Brassica rapa $\mathrm{L}$. & Brassicaceae & Vegetable & Leaf \\
\hline Sawi putih [Field mustard] & Brassica rapa var. pekinensis (Lour.) Hanelt & Brassicaceae & Vegetable & Leaf \\
\hline Sawo kecik [Sapodilla] & Manilkara kauki (L.) Dubard & Sapotaceae & Fruit & Fruit \\
\hline Sawo manila [Sapodilla] & Manilkara zapota (L.) P.Royen & Sapotaceae & Fruit & Fruit \\
\hline Selada air [Watercress] & Nasturtium officinale R.Br. & Brassicaceae & Vegetable & Leaf \\
\hline Selada bokor [Garden lettuce] & Lactuca sativa $\mathrm{L}$ & Asteraceae & Vegetable & Leaf \\
\hline Selada bokor ungu [Garden lettuce] & Lactuca sativa $\mathrm{L}$. & Asteraceae & Vegetable & Leaf \\
\hline Seledri [Wild celery] & Apium graveolens $\mathrm{L}$. & Apiaceae & Vegetable & Leaf, stem \\
\hline Semongko [Watermelon] & $\begin{array}{l}\text { Citrullus lanatus (Thunb.) Matsum. \& } \\
\text { Nakai }\end{array}$ & Cucurbitaceae & Fruit & Fruit \\
\hline Sereh [Lemon grass] & Cymbopogon citratus (DC.) Stapf & Poaceae & Spices & Stem \\
\hline Sirsak [Soursop] & Annona muricata $\mathrm{L}$. & Annonaceae & Fruit & Fruit \\
\hline Stroberi [Strawberry] & $\begin{array}{l}\text { Fragaria } \times \text { ananassa } \text { (Duchesne ex } \\
\text { Weston) Duchesne ex Rozier }\end{array}$ & Rosaceae & Fruit & Fruit \\
\hline Tales putih [Taro] & Colocasia esculenta (L.) Schott & Araceae & $\begin{array}{l}\text { Additional staple } \\
\text { food }\end{array}$ & Tuber \\
\hline Tales ungu [Taro] & Colocasia esculenta (L.) Schott & Araceae & $\begin{array}{l}\text { Additional staple } \\
\text { food }\end{array}$ & Tuber \\
\hline Tauge, totkolan, cambah [Mungbean] & Vigna radiata (L.) R.Wilczek & Fabaceae & Vegetable & Fruit \\
\hline Telo kuning [Cassava] & Manihot esculenta Crantz. & Convolvulaceae & $\begin{array}{l}\text { Additional staple } \\
\text { food }\end{array}$ & Tuber \\
\hline Telo ungu [Cassava] & Manihot esculemta Crantz. & Convolvulaceae & $\begin{array}{l}\text { Additional staple } \\
\text { food }\end{array}$ & Tuber \\
\hline Temulawak [Java ginger] & Curcuma zanthorrhiza Roxb. & Zingiberaceae & $\begin{array}{l}\text { Spices, traditional } \\
\text { medicine }\end{array}$ & Rhizome \\
\hline Terong belanda [Eggplant] & Solanum betaceum Cav. & Solanaceae & Fruit & Fruit \\
\hline Terong ijo [Eggplant] & Solanum melongena $\mathrm{L}$. & Solanaceae & Vegetable & Fruit \\
\hline Terong pepino [Eggplant] & Solanum muricatum Aiton & Solanaceae & Fruit & Fruit \\
\hline Terong ungu [Eggplant] & Solanum melongena $\mathrm{L}$. & Solanaceae & Vegetable & Fruit \\
\hline Timun [Cucumber] & Cucumis sativus $\mathrm{L}$. & Cucurbitaceae & Vegetable & Fruit \\
\hline Tomat abang [Tomato] & Lycopersicum esculentum Mill. & Solanaceae & Spice, vegetable & Fruit \\
\hline Tomat ijo [Tomato] & Lycopersicum esculentum Mill. & Solanaceae & Spice, vegetable & Fruit \\
\hline Tomat kecil [Tomato] & Lycopersicum esculentum Mill. & Solanaceae & Spice, vegetable & Fruit \\
\hline Tumbar [Coriander] & Coriandrum sativum $\mathrm{L}$. & Apiaceae & Spices & Fruit \\
\hline Waluh [Giant pumpkin] & Cucurbita maxima Duchesne & Cucurbitaceae & Vegetable & Fruit \\
\hline Waluh jepang/Kabocha [Giant pumpkin] & Cucurbita maxima Duchesne & Cucurbitaceae & Vegetable & Fruit \\
\hline Wortel [Wild carrot] & Daucus carota $\mathrm{L}$. & Apiaceae & Vegetable & $\begin{array}{l}\text { Tuberosus } \\
\text { root }\end{array}$ \\
\hline
\end{tabular}

\section{Plant part}

Based on data obtained, it can be inferred that the cause of high plant species diversity is having a high diversity of plant parts which are used for various uses, including staple food, additional staple food, fruit, vegetable, spice, spice as vegetable, and spice with medicinal values. We encountered the dominant parts of edible plants that are commonly traded in the Beringharjo market were fruit $(92$ species; $98.9 \%$ ), leaf (18 species; $19.3 \%)$, seed (12 species; $12.9 \%$ ), rhizome (9 species; $9.6 \%$ ), and bulb (8 species; $8.6 \%$ ) (Figure 8). Since the fruit plants have been recorded high diversity, the predominant plant parts were also high. Besides, the plant parts of many vegetable species, including cucumber, cayenne pepper, sponge gourd, caisin, cowpea, blackeyed pea, bitter gourd, mungbean, eggplant, tomato, and great pumpkin, were mainly fruits. 


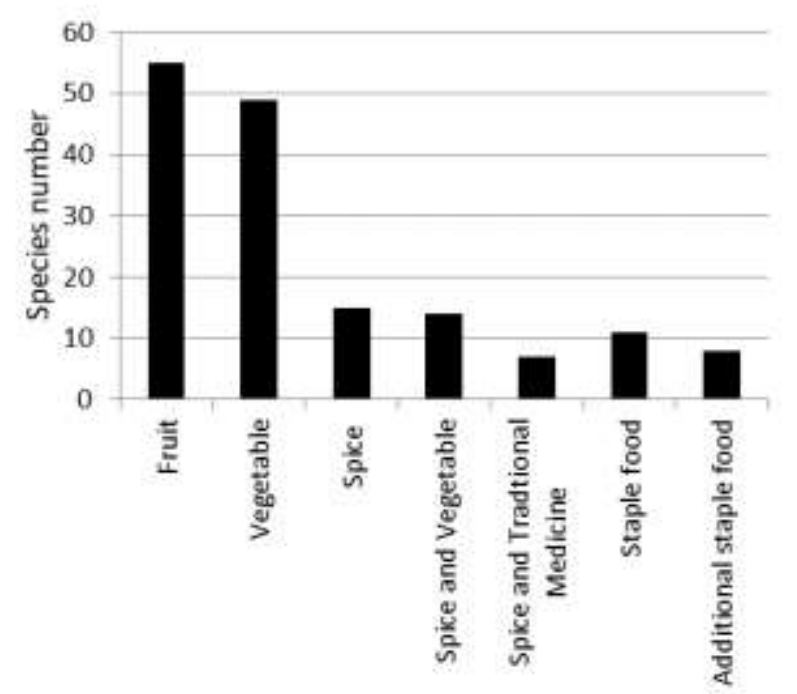

Figure 5. Main use-categories of edible plant species commonly traded in the Beringharjo market, Yogyakarta, Indonesia

Table 2. Plant species and landraces sold in Beringharjo Market, Yogyakarta, Indonesia

\begin{tabular}{|c|c|c|c|}
\hline Species & $\begin{array}{c}\text { Vernacular } \\
\text { name }\end{array}$ & $\begin{array}{c}\text { Common } \\
\text { name }\end{array}$ & $\begin{array}{l}\text { Landrace } \\
\text { number }\end{array}$ \\
\hline Allium sativum $\mathrm{L}$ & $\begin{array}{l}\text { Bawang } \\
\text { putih }\end{array}$ & Garlic & 2 \\
\hline Brassica rapa $\mathrm{L}$ & Sawi & Field mustarc & 3 \\
\hline Colocasia esculenta (L.) Schott & Tales & Coco yam & 2 \\
\hline Cucurbita maxima Duchesne & Waluh & $\begin{array}{l}\text { Giant } \\
\text { pumpkin }\end{array}$ & 2 \\
\hline Lactuca sativa $\mathrm{L}$ & Selada bokor & Lettuce & 2 \\
\hline Lycopersicum esculentum Mill & Tomat & Tomato & 3 \\
\hline Malus domestica Borkh & Apel impor & Apple & 3 \\
\hline Mangifera indica $\mathrm{L}$ & Pelem & Mango & 2 \\
\hline Manihot esculenta Crantz & Telo & Cassava & 2 \\
\hline Manilkara kauki (L.) Dubard & Sawo & Manilkara & 2 \\
\hline Musa x paradisiaca $\mathrm{L}$ & Gedang & Banana & 11 \\
\hline Oryza sativa $\mathrm{L}$ & Beras & Rice & 10 \\
\hline Salacca zalacca (Gaertn.) Voss & Salak & Snake fruit & 2 \\
\hline Vitis vinifera $\mathrm{L}$ & Anggur hijau & Grape & 3 \\
\hline Zea mays $\mathrm{L}$ & Jagung & Corn & 3 \\
\hline Zingiber officinale Roscoe & Jahe & Ginger & 4 \\
\hline Total & & & 61 \\
\hline
\end{tabular}

In terms of plant parts traded, the Ujungberung market is similar to the Beringharjo market, the market traded fruit (90 species; $75.0 \%$ ), leaves (41 species; $34.2 \%)$, seeds (27 species; $22.5 \%$ ), and rhizome (9 species; $7.5 \%$ ) (Iskandar et al 2018).

\section{Trade chain system}

The Beringharjo market has been an important role as a central market to accommodate various edible plant commodities that are supplied from the local farmers, and other traditional markets of Yogyakarta, including Tempel Market and Gamping Market of Sleman regency. Besides, various addible plant edible commodities are supplied from some areas of Central Java, such as Boyolali, Klaten, Kali Angkrik, Magelang, Semarang, Purwodadi, Cilacap, Wonoso and Muntilan (Figure 8).
Table 3. Families of edible plants traded in Beringharjo Market, Yogyakarta, Indonesia

\begin{tabular}{|c|c|c|}
\hline Family & $\begin{array}{l}\text { Species } \\
\text { number }\end{array}$ & Percentage \\
\hline Achariaceae & 1 & 1.0 \\
\hline Alismataceae & 1 & 1.0 \\
\hline Alliaceae & 9 & 9.6 \\
\hline Amaranthaceae & 4 & 4.3 \\
\hline Anacardiaceae & 3 & 3.2 \\
\hline Annonaceae & 1 & 1.0 \\
\hline Apiaceae & 3 & 3.2 \\
\hline Araceae & 3 & 3.2 \\
\hline Arecaceae & 5 & 5.3 \\
\hline Asteraceae & 3 & 3.2 \\
\hline Brassicaceae & 10 & 10.7 \\
\hline Bromeliaceae & 1 & 1.0 \\
\hline Cactaceae & 1 & 1.0 \\
\hline Caricaceae & 1 & 1.0 \\
\hline Clusiaceae & 1 & 1.0 \\
\hline Convolvulaceae & 3 & 3.2 \\
\hline Cucurbitaceae & 9 & 9.6 \\
\hline Dioscoreaceae & 1 & 1.0 \\
\hline Ebenaceae & 1 & 1.0 \\
\hline Euphorbiaceae & 2 & 2.1 \\
\hline Fabaceae & 16 & 17.2 \\
\hline Gnetaceae & 1 & 1.0 \\
\hline Lamiaceae & 2 & 2.1 \\
\hline Lauraceae & 1 & 1.0 \\
\hline Moraceae & 1 & 1.0 \\
\hline Musaceae & 12 & 12.9 \\
\hline Myrtaceae & 3 & 3.2 \\
\hline Oxalidaceae & 1 & 1.0 \\
\hline Pandanaceae & 1 & 1.0 \\
\hline Piperaceae & 1 & 1.0 \\
\hline Poaceae & 14 & 15.0 \\
\hline Rosaceae & 5 & 5.3 \\
\hline Rutaceae & 8 & 8.6 \\
\hline Sapindaceae & 2 & 2.1 \\
\hline Sapotaceae & 2 & 2.1 \\
\hline Solanaceae & 13 & 13.9 \\
\hline Vitaceae & 3 & 3.2 \\
\hline Zingiberaceae & 10 & 10.7 \\
\hline Total & 93 & 100.0 \\
\hline
\end{tabular}

The local productions of the agricultural sector, i.e. fruits and vegetables that are traded in Beringharjo Market, are directly supplied by local farmers of Yogyakarta in small quantities. For example, various local fruits, including ceplukan (Physalis angulata), sawo kecik (Manilkara kauki), jambu dalaru/jambu air (Syzygium aqueum), and salak (Salacca zalacca) are known among other fruits that are predominantly traded in the Beringharjo market. These fruits are not available throughout the year but depend on the fruiting season (rainy season). During the fruiting season, the supply has increased, which resulted in the price is getting lower. Besides, some local vegetables, including genjer (Limnocharis flava), kangkung (Ipomoea aquatica), and bayem (Amaranthus tricolor) are commonly supplied by local farmers of Yogyakarta. These vegetables are cultivated in small-scale farming systems, including gardens and home gardens. 


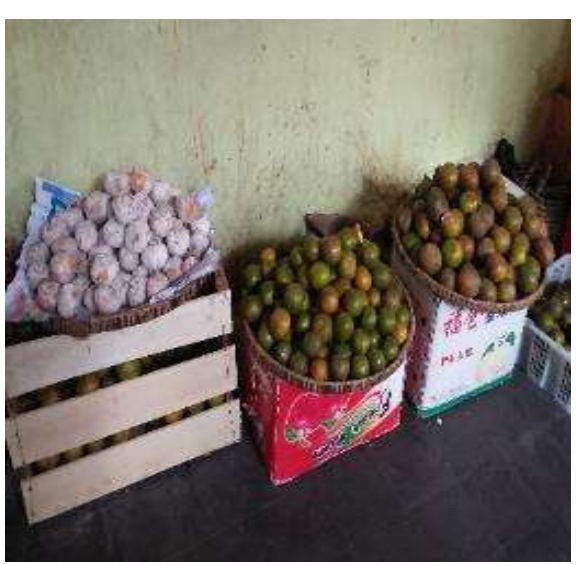

$\mathbf{A}$

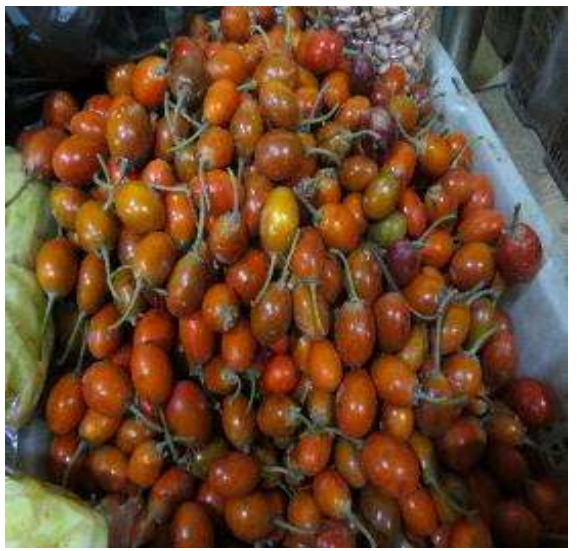

B

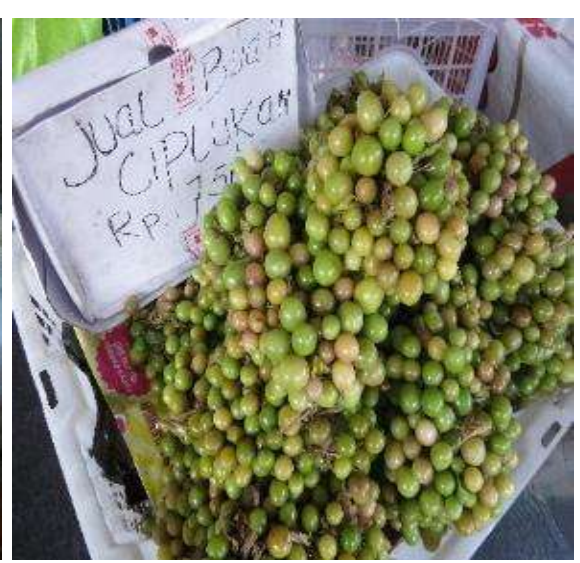

C

Figure 6. A.Local fruits consist of kelendung/kesemek (Diospyros kaki) and jeruk (Citrus sinensis), B. Sawo kecik (Manilkara kauki), and C. Ciplukan (Physalis angulata) are commonly traded in Beringharjo market, Yogyakarta, Indonesia
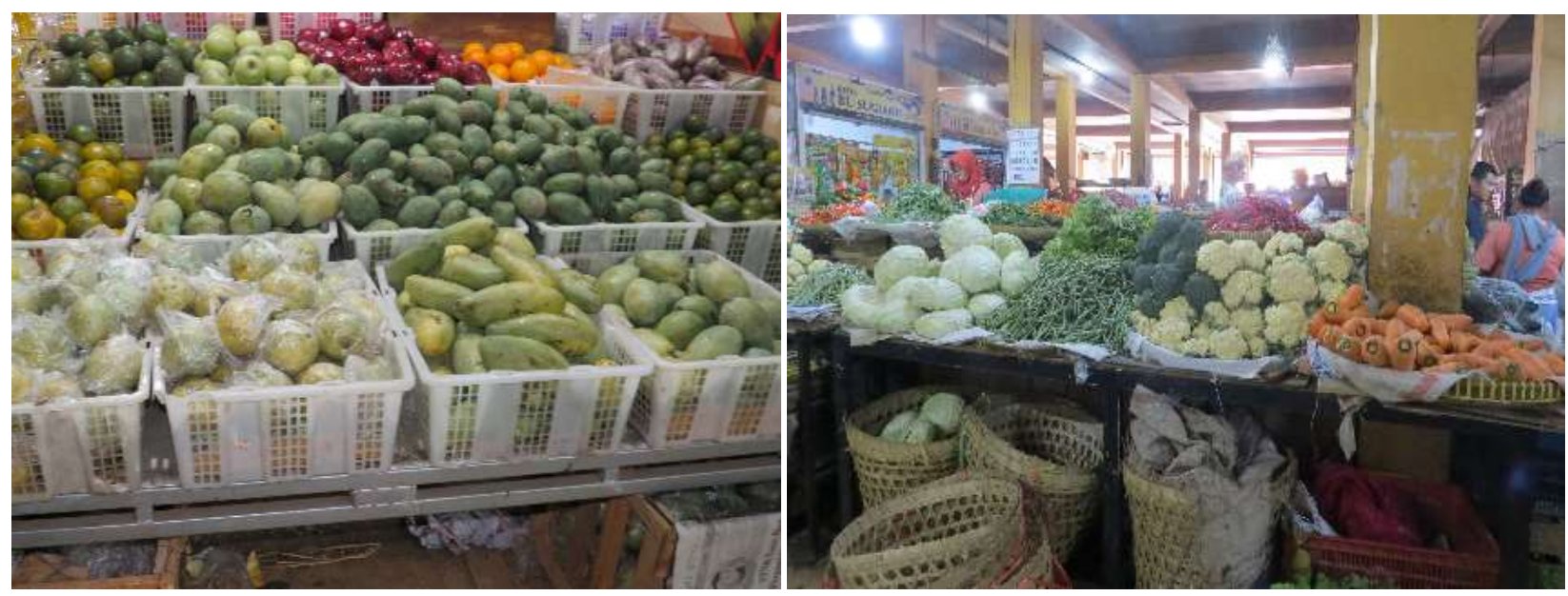

Figure 7. Various fruits consist of mangga (Mangifera indica), jeruk (Citrus sinensis), apel Malang (Malus domestica), and apel impor (Malus domestica) [left]; and vegetables consist of kubis (Brassica oleracea), kacang panjang (Vigna unguiculata), wortel (Daucus carota), and tomat (Lycopersicum esculentum) [right] predominantly traded in the Beringharjo market, Yogyakarta, Indonesia

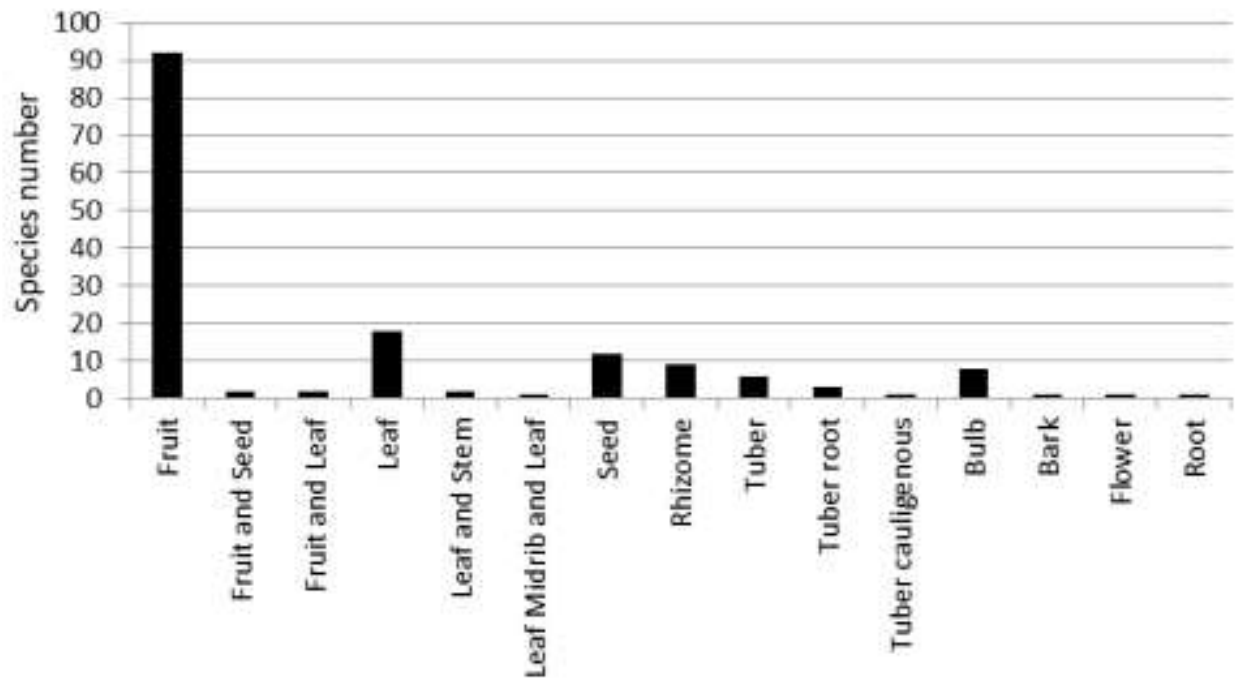

Figure 8. Plant parts commonly traded in Beringharjo traditional market, Yogyakarta, Indonesia 
The local productions of the agricultural sector, i.e. fruits and vegetables that are traded in Beringharjo Market, are directly supplied by local farmers of Yogyakarta in small quantities. For example, various local fruits, including ceplukan (Physalis angulata), sawo kecik (Manilkara kauki), jambu dalaru/jambu air (Syzygium aqueum), and salak (Salacca zalacca) are known among other fruits that are predominantly traded in the Beringharjo market. These fruits are not available throughout the year but depend on the fruiting season (rainy season). During the fruiting season, the supply has increased, which resulted in the price is getting lower. Besides, some local vegetables, including genjer (Limnocharis flava), kangkung (Ipomoea aquatica), and bayem (Amaranthus tricolor) are commonly supplied by local farmers of Yogyakarta. These vegetables are cultivated in small-scale farming systems, including gardens and home gardens.

In addition to supply from local areas, some areas of Central Java have commonly supplied various edible plants to the Beringharjo market. Some vegetable plants, including kubis (Brassica oleracea var. capitate), kentang (Solanum tuberosum), seledri (Apium graveolens), kenikir (Cosmos caudatus), sawi (Brassica rapa), and wortel (Daucus carota) are supplied from the regencies of Boyolali and Klaten, Central Java. Some supplier usually send their vegetable commodities to the traders who sell the vegetable outside of the market building, while the vegetable traders who trade inside the building market usually have their regular suppliers.

Based on data obtained, this study encountered 93 species belonging to 37 families with 159 landraces. Like the Beringharjo market, the Ujungberung market traded 120 species of edible plants belonging to 44 families, and 188 landraces (Iskandar et al. 2018), while the Karangwangi market, located in South Cianjur West Java, contained 108 species belonging to 23 families of medicinal plant species, in some traditional markets located in the district of Tabanan Bali recorded 52 plants belonging to 30 families (Sujarwo et al. 2018), six traditional markets in Pati, Central Java, documented 126 plant species belonging to 55 families as botanical Simplicia, mainly from the Zingiberaceae family (Irwanta et al. 2015), in the Kabanjahe market, North Sumatra, recorded 4019 species of medicinal plants belonging to 122 families (Silalahi 2015). Other traditional markets in Asia, such as the traditional markets of Brunei Darussalam and Vietnam, have also high diversity of plants commonly traded. In the Tamu Kainggeh market, located in Bandar Seri Begawan, Brunei Darussalam, recorded 104 plant taxa consisting of 26 natives and 2 endemics (Franco et al. 2020), and in 32 markets of Son La Province, Vietnam recorded 99 medicinal plant species belonging to 57 families (Nguyen et al. 2019). Similarly, in the traditional market of Latin America, encountered 409 plant species belonging to 122 families, traditionally used for the treatment of a total of 19 disease-categories with 318 applications (Bussmann et al. 2018). It is generally accepted that traditional markets have a very high diversity of plants traded and happened across cultures in different countries in Asia, i.e. Indonesia, Brunei Darussalam, Vietnam, and Latin America.

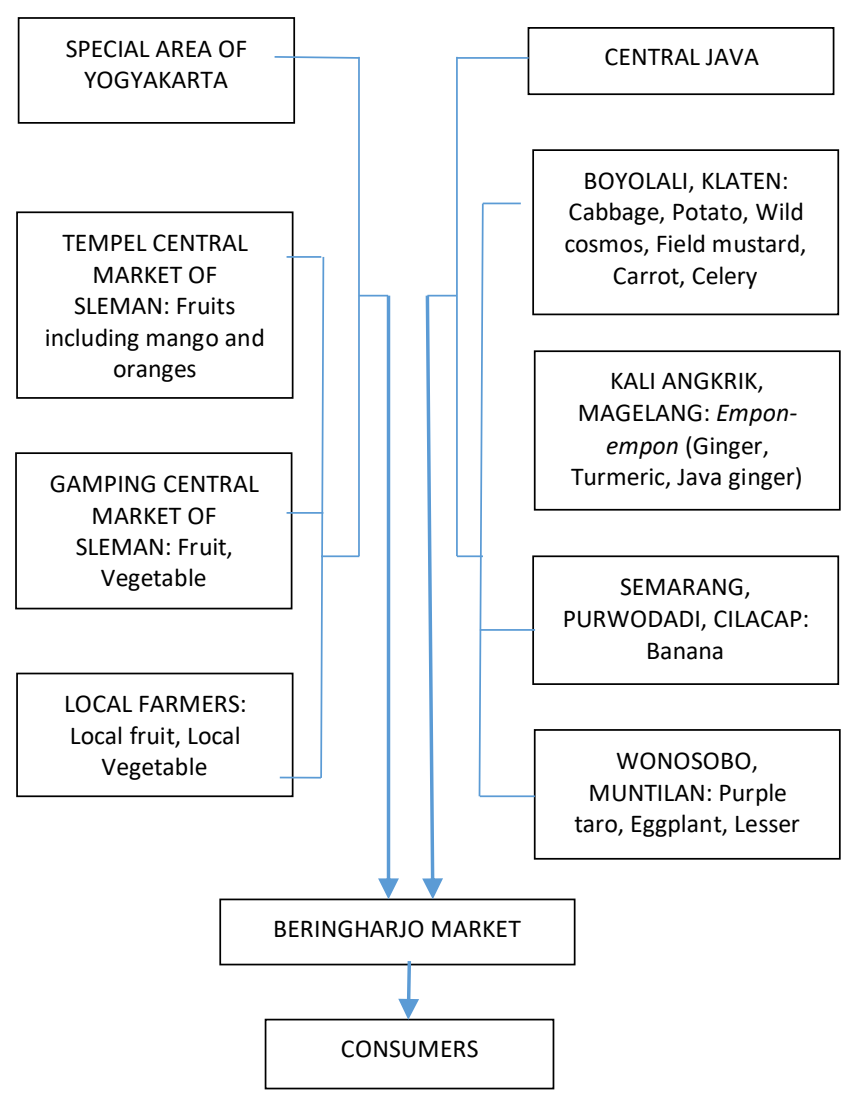

Figure 9. Trade chain system for edible plant commodities traded in the Beringharjo market

In addition to a high diversity of plants, the traditional markets in many countries of Asia and Latin America have an important role as the main place for uniting, concentrate, maintain, and diffuse empirical knowledge about plant resources and therefore can guarantee the resilience and maintenance of Traditional Ecological Knowledge (TEK) concerning useful plant species (Monteiro 2010; Nguyen et al 2019; Franco et. 2020 ). In other words, the traditional market represents characteristics of a particular culture or society, the cultural and biological diversity of the region (Alburquerque et al. 2014).

This study can be concluded that the Beringharjo market has been established for a long time at least in 1758 . Like other traditional markets in Indonesia, the Beringharjo traditional market has been an important role in the development of local economic activities, as the main place for the transaction of various edible plants and a melting pot of ethnics and biological diversity, also a property to make the important center of biocultural diversity at the local level. Based on ethnobotanical data, it was revealed that 93 species belonging to 37 families with 159 landraces in total. The Beringharjo market has traditionally traded a high diversity of edible plants that are supplied from local farmers from the provinces Yogyakarta itself and Central Java. Therefore, this traditional market has an important role in enhancing the local economy and contributing to promoting and conserving local plant diversity in the region. 


\section{ACKNOWLEDGEMENTS}

We are grateful to the head of the Agency of Trade, Industry and Market of Yogyakarta Province for permitting our study. We would like to acknowledge the informants (traders) of Beringharjo Market, Yogyakarta who providing information on various aspects of the traditional market and various edible plants traded. We would also like to acknowledge the SIMLITABMAS Ministry of Education for funding the Research project of Dr. Budiawati Supangkat Contract Number 10/E1/KP.PTNBH/2019, and Agreement/Contract Number 5097c/UN6.G/LT/2019. Padjadjaran University granted permission for the work. Oral consent was obtained from the community and traders at the Beringharjo Market, Yogyakarta.

\section{REFERENCES}

Albuquerque UP, Monteiro JM, Ramos MA, de Amorim ELC, Alves RRN. 2014. Ethnobiological Research in Public Markets. In Albuquerque UP, Cruz da Cunha LVF, Paiva de Lucena RF, Alves RRN (eds), Methods and Techniques in Ethnobiology and Ethnoecology. Humana Press, New York.

Alfian RL, Iskandar J, Iskandar BS, Suroso, Ermandara DP, Mulyanto D, Partasasmita R. 2020. Fish species, traders, and trade in traditional market: case study in Pasar Baru, Balikpapan city, East Kalimantan, Indonesia. Biodiversitas 21 (1): 393-406. DOI 10.13057/biodiv/d210146.

Alves RRN, Oliveira MGG, Barboza RRD, Lopez LCS, Oleiveira MGG. 2010. An Ethnozoological survey on medical animals commercialized in Markets of Camprina Grande, NE Brazil. Human Ecol 17 (1): 11 17.

Arman S. 1996. Diversity and trade of market fruit in West Kalimantan. In Padoch C, Peluso NL (eds), Borneo in Transition: People, Forest, Conservation, and Development. Oxford University Press, New York

Backer CA, Bakhuizen v.d Brink Jr.RC. 1968. Flora of Java, Vol. 1-3. Wolters Noordhoff NV, Groningen.

Bautista-Cruz A, Arnaud-Vinas MR, Martinez-Gutierrez GA, SanchezMedina PS, Perez-Pacheco R. 2011. The Traditional medicinal and food uses of four plants in Oaxaca, Mexico. J Plant Res 5 (15): 3404 3411.

Bussmann RW, Zamrana NYP, Romero C, Hart RE. 2018. Astonishing diversity-the medicinal plant markets of Bogota, Columbia. J Ethnobiol Ethnomed 14: 43. DOI: 10.1186/s13002-018-0241-8.

Cahya GA, Mahendra YKD, Damanik II. 2017. Malioboro as a value of special district of Yogyakarta City. IOP Conf Ser Earth Environ Sci 70: 012055. DOI: 10.10.88/1755-1315/70/1/012055.

Cunningham AB. 2001. Applied Ethnobotany: People, Wild Plant Use and Conservation. Earthscan, London.

Dwinanto A, Soemarworo RS, Palar RMA. 2019. Sirih pinang culture and opportunities of its preservation in West Sumba, Indonesia. Patanjala 11 (3): 363-379. DOI: 10.30959/patanjala.vl li3.543. [Indonesian].

Franco FM, Chaw LL, Bakar N, Abas STNH. 2020. Socializing over fruits and vegetables: the biocultural importance of an open-air market in Bandar Seri Begawan, Brunei, Darussalam. J Ethnobiol Ethnomed 16:6. DOI: 10.1186/s13002-020-0356-6.

Herliana ET. 2015. Preserving Javanese culture through retail activities in Pasar Beringharjo, Yogyakarta. Procedia-Soc Behav Sci 184 (2015) 206-213. DOI: 10.1016/jsbspro.2015.05.081.

Heyne K. 1987. Useful Plant in Indonesia. Badan Litbang Kesehatan, Jakarta. [Indonesian].

Irwanta E, Himat A, Zuhud EAM. 2015. Diversity of vegetable simplicial and traditional medicine products on the market in Pati Regency, Central Java. Media Konservasi 20 (3): 197-204. [Indonesian].
Iskandar BS, Iskandar J, Irawan B, Partasasmit R. 2018. Traditional markets and diversity of edible plant trading: case study in Ujung Berung, Bandung, West Java, Indonesia. Biodiversitas 19 (2):437452. DOI: 10.13057/biodiv/d190211.

Iskandar BS, Iskandar J, Irawan B. 2020a. The role of village markets in supporting the community's economy and conservation of biological diversity: a case study in Cidaun District, Cianjur, West Java. In Fakhriah EL, Deliarnoor NA (eds.). The Socio Humanities Professor's Thought in Welcoming the Adaptation of New Habits. UNPAD Press, Bandung. [Indonesian]

Iskandar BS, Iskandar J, Partasasmita R, Irawan B. 2020b. Various medical plants traded in the village market of Karangwangi village, Southern Cianjur, West Java, Indonesia. Biodiversitas 21 (9): 44404456. DOI: 10.13057/biodiv/d210963.

Lukzaj L, Lamxay V, Tongchan K, Xayphakatsa K, Phimakong K, Radavanh S, Kanyasone V, Pietras M, Karbarz M. 2021. Wild food plants and sold in the markets of Luang Prabang, Lao PDR. J Ethnobiol Ethnomed 17 (6): 1-27. DOI: 10.1186/s13002-020-00423y.

Manzanero-Medina GI, Vasquez-Davila MA, Lustre-Sanchez H, PerezHerr A. 220. Ethnobotany of food plans (qualities) sold in two traditional market of Oaxaca, Mexico. South Afr J Bot 130: 215-223.

Martin GJ. 1995. Ethnobotany: A Method Manual. Chapman \& Hall, London.

Monteiro JM, Araujo EDL, Amorim ELC, Albuquerque UPD. 2010. Local markets and medical plant commerce: A review with emphasis on Brazil. Econ Bot 64 (4): 352-366. DOI: 10.1007/s7/s12231-0109132-1.

Newing H, Eagle CM, Puri RK, Watson CW. 2011. Conducting Research in Conservation: A Social Science Perspective. Routledge, London.

Nguyen MLT. 2005. Cultivated plant collections from market place. Ethnobot Res Appl 3: 5-15.

Nguyen TS, Xia NH, Chu TV, Sam HV. 2019. Ethnobotanical study on medical plant in traditional markets of Son La province, Vietnam. Forest Soc 3 (2): 171-192. DOI: 10.24259/fs. V3i2.6605.

Partoharjono S, Grubben GJH. 1996. Plant Resources of South-East Asia No. 10. Cereals. Prosea, Bogor.

Si Z, Scott S, McCordic C. 2016. Supermarkets, West Markets and Food Patronage in Nanjing, China. Hungary Cities Partnership Discussion paper No. 4, pp. 1-14. http://hungary cities.net/publicationcategory/hungary-cities-paper/.

Siemonsa JS, Grubben GJH. 1996. Plant resources of South-East Asia No. 8 Vegetables. Pudoc Scientific Publisher, Wageningen, Netherlands.

Silalahi M, Nisyawati, Waluyo EB, Supriatna J, Mangunwardoyo W. 2015. The local knowledge of medical plant traders and diversity of medical plants in the Kabanjahe traditional market, North Sumatra, Indonesia. J Ethnopharmacol 175: 432-443. DOI: 10.1016/j.jep.2015.09.009.

Siregar M. 2006. Review: Species diversity of local fruit trees in Kalimantan -Problems of Conservation and its development. Biodiversitas 7 (1): 94-99. DOI: 10.13057/biodiv/d070123.

Smith JK. 2011. The Everyday Life of Food: The Cultural Economy of the Traditional Market in England. [Dissertation]. Faculty of Applied Sciences, University of Gloucestershire, UK.

Spradley J. 1980. Participant observation. Holt, Rinehart and Winston Publisher, Minnesota.

Statistical Data of Yogyakarta. 2012. Yogyakarta in Figures 2012. BPS, Yogyakarta.

Sujarwo W, Lugrayasa IN, Kuswantoro F. 2018. Ethnobotanical study of three traditional markets in Tabanan Regency Bali. Berita Biologi 17 (3): 283-297. DOI: 10.14203/beritabiologi.v17i3.3342. [Indonesian]

Supangkat BI. 2012. Market and women traders in Ujung Berung market, Bandung [Dissertation]. Department of Anthropology, Faculty of Social and Political Science, University of Indonesia, Depok. [Indonesian]

Titania F, Rios M, Roomero-Beaviades JC, Cruz Rot M. 2016. Medicinal plant sold at traditional markets in South Ecuador. J Ethnobiology and Ethnomedicine 12: 29. DOI: 10.1186/s 13002-016-0100-4. 